\title{
Oral Magnesium Supplements Reduce Erythrocyte Dehydration in Patients with Sickle Cell Disease
}

\author{
Lucia De Franceschi, , Dora Bachir,, Frederic Galacteros,; Gil Tchernia,§ Therese Cynober,§ Seth Alper," Orah Platt," \\ Yves Beuzard, ** and Carlo Brugnara"l \\ *Department of Medicine, University of Verona, Verona, 37134 Italy; ${ }^{\ddagger} I N S E R M$ Unit 91, Hôpital H. Mondor, Creteil, 94010 France; \\ ${ }^{\S}$ Centre Hospitalier de Bicêtre, Le Kremlin Bicêtre, 94275 France; ${ }^{\| M o l e c u l a r ~ M e d i c i n e ~ U n i t ~ a n d ~ R e n a l ~ U n i t, ~ B e t h ~ I s r a e l ~ D e a c o n e s s ~}$ \\ Medical Center, Boston, Massachusetts 02115; "Department of Laboratory Medicine, Department of Medicine, and Department of \\ Pathology, Children's Hospital, Harvard Medical School, Boston, Massachusetts 02115; and **Experimental Laboratory of Gene \\ Therapy, Hôpital St. Louis, Paris, 75475 France
}

\begin{abstract}
Intracellular polymerization and sickling depend markedly on the cellular concentration of sickle hemoglobin (Hb S). A possible therapeutic strategy for sickle cell disease is based on reducing the cellular concentration of $\mathrm{Hb} \mathrm{S}$ through prevention of erythrocyte dehydration. The K-Cl cotransporter is a major determinant of sickle cell dehydration and is inhibited by increasing erythrocyte Mg content.

We studied 10 patients with sickle cell disease before treatment and after 2 and 4 wk of treatment with oral $\mathrm{Mg}$ supplements (0.6 meq/kg/d Mg pidolate). Hematological parameters, erythrocyte $\mathrm{Na}, \mathrm{K}$, and $\mathrm{Mg}$ content, erythrocyte density, membrane transport of $\mathrm{Na}$ and $\mathrm{K}$, and osmotic gradient ektacytometry were measured. We found significant increases in sickle erythrocyte $\mathrm{Mg}$ and $\mathrm{K}$ content and reduction in the number of dense sickle erythrocytes. Erythrocyte $\mathrm{K}-\mathrm{Cl}$ cotransport was reduced significantly. We also observed a significant reduction in the absolute reticulocyte count and in the number of immature reticulocytes. Ektacytometric analysis showed changes indicative of improved hydration of the erythrocytes. There were no laboratory or clinical signs of hypermagnesemia. Mild, transient diarrhea was the only reported side effect. We conclude that oral Mg supplementation reduces the number of dense erythrocytes and improves the erythrocyte membrane transport abnormalities of patients with sickle cell disease. (J. Clin. Invest. 1997. 100:1847-1852.) Key words: sickle cell • erythrocytes • antisickling agents $\bullet$ potassium $\bullet$ carrier proteins
\end{abstract}

\section{Introduction}

The delay time for sickle hemoglobin $(\mathrm{Hb} \mathrm{S})^{1}$ polymerization in $\mathrm{Hb} \mathrm{S}$-containing (SS) erythrocytes has an inverse exponential relationship to the cellular concentration of $\mathrm{Hb} \mathrm{S}$ to its 20

Address correspondence to Carlo Brugnara, M.D., Department of Laboratory Medicine, The Children's Hospital, 300 Longwood Avenue, Bader 760, Boston, MA 02115. Phone: 617-355-6347; FAX: 617355-6081; E-mail: brugnara@a1.tch.harvard.edu

Received for publication 21 March 1997 and accepted in revised form 1 August 1997.

J. Clin. Invest.

(C) The American Society for Clinical Investigation, Inc. 0021-9738/97/10/1847/06 \$2.00

Volume 100, Number 7, October 1997, 1847-1852

http://www.jci.org 40th power (1). The presence of intracellular $\mathrm{Hb} \mathrm{S}$ polymers also depends on cellular $\mathrm{Hb} \mathrm{S}$ concentration (2). Therefore, small changes in $\mathrm{Hb} \mathrm{S}$ concentration affect markedly hemoglobin polymerization and cell sickling. One of the distinguishing characteristics of the sickle erythrocyte is the presence of dense erythrocytes that are formed as a consequence of cell dehydration and $\mathrm{K}$ loss. Dense erythrocytes are thought to play an important role in the vasoocclusive manifestations of this disease $(3,4)$.

Therapeutic strategies for sickle cell (homozygous for $\mathrm{Hb} \mathrm{S}$, or SS) disease aim at reducing $\mathrm{Hb} \mathrm{S}$ polymerization. Hydroxyurea achieves this effect by increasing the cellular concentration of fetal hemoglobin ( $\mathrm{Hb} \mathrm{F}$ ) which reduces $\mathrm{Hb} \mathrm{S}$ polymerization to values seen in patients with the milder heterozygous for sickle and $\mathrm{C}$ hemoglobin (SC) disease (5-7). An additional therapeutic strategy for SS disease is based on reducing the cellular concentration of $\mathrm{Hb} \mathrm{S}$ by preventing cell dehydration and $\mathrm{K}$ loss via the blockade of specific membrane cation transport systems. The two major pathways responsible for $\mathrm{K}$ loss and dehydration of SS erythrocytes are the $\mathrm{Ca}^{2+}$-activated $\mathrm{K}$ channel (Gardos) (8) and the K-Cl cotransport $(9,10)$. The imidazole antimycotic clotrimazole specifically induces blockade of the Gardos channel (11). With the use of this inhibitor, the role of the Gardos channel in SS erythrocyte dehydration has been demonstrated in vitro (12), in vivo in the SAD mouse, a transgenic model of SS disease (13), and in patients with SS disease (14).

We and others have explored the role of erythrocyte $\mathrm{Mg}$ in modulating the $\mathrm{K}-\mathrm{Cl}$ cotransport system of normal (15) and SS erythrocytes in vitro $(16,17)$. Several reports have suggested that erythrocyte $\mathrm{Mg}$ content can be increased with dietary $\mathrm{Mg}$ supplementation in patients with diabetes $(18,19)$. We have shown recently that dietary $\mathrm{Mg}$ supplements improved erythrocyte abnormalities and increased hemoglobin in the SAD mouse (20). In this report, we test the hypothesis that dietary $\mathrm{Mg}$ supplementation may induce beneficial changes in SS erythrocyte dehydration in patients with SS disease.

\footnotetext{
1. Abbreviations used in this paper: ALT, serum glutamic pyruvate transaminase; AST, serum glutamic oxaloacetic transaminase; BUN, blood urea nitrogen; $\mathrm{CBC}$, complete blood count; $\mathrm{CH}$, hemoglobin content; $\mathrm{CV}$, corpuscular volume; $\mathrm{D}_{50}$, median density; DI, deformability index; DW, distribution width; $\mathrm{Hb} \mathrm{F}$, fetal hemoglobin; $\mathrm{Hb}$ S, sickle cell hemoglobin; HC, hemoglobin concentration; HDW, hemoglobin DW; M, mean; $\mathrm{O}^{\prime}$, osmolality value in the hyperosmolar region at which the DI reaches half the maximum value; r, reticulocyte; $\mathrm{R}_{60}$, median $60 \%$ density range; RDW, red cell volume DW; SC, heterozygous for $\mathrm{Hb} \mathrm{S}$ and $\mathrm{C}$ hemoglobin; SS, homozygous for $\mathrm{Hb} \mathrm{S}$.
} 


\section{Methods}

Patient selection. Individuals over $18 \mathrm{yr}$ of age with SS disease were eligible. Inclusion criteria included normal renal and liver function, performance status of $70 \%$ or greater, and no blood transfusions during the preceding $3 \mathrm{mo}$. An investigator explained the study completely to each participant, who then gave written informed consent. A negative pregnancy test was required for female subjects. All the patients were treated as outpatients. No patients were hospitalized during the study.

Study protocol. In the initial phase, erythrocyte and plasma $\mathrm{Mg}$ levels were determined in 21 patients with SS disease, 24 patients with SC disease, and 17 normal controls.

11 of the SS patients were enrolled in the dietary Mg supplementation study. One of the patients did not return after the baseline studies and could not be reached for follow-up. 10 patients completed the $\mathrm{Mg}$ supplementation protocol.

The following studies were performed three times: at the time of entry, after $2 \mathrm{wk}$ and after $4 \mathrm{wk}$ of $\mathrm{Mg}$ therapy-complete blood counts (CBC), electrolytes, blood urea nitrogen (BUN), creatinine, serum glutamic pyruvate transaminase (ALT), serum glutamic oxaloacetic transaminase (AST), total and direct bilirubin, erythrocyte phthalate density profiles, and membrane transport studies (described in detail below).

Subjects were given 0.6 meq $\mathrm{mg}$ pidolate/kg body wt/d (MAG-2; Theraplix, Paris, France), divided into two oral daily doses, for $4 \mathrm{wk}$. This dosage corresponds to $504 \mathrm{mg}$ of supplemental $\mathrm{Mg}$ per day in a $70-\mathrm{kg}$ subject. The daily $\mathrm{Mg}$ intake of normal subjects estimated from dietary history is $418 \pm 120 \mathrm{mg}$ for males and $343 \pm 94 \mathrm{mg}$ for females (21). This dosage is slightly higher in daily elemental $\mathrm{Mg}$ than the dose shown to increase erythrocyte $\mathrm{Mg}$ in two prior studies in patients with diabetes mellitus $(18,19)$.

$\mathrm{Mg}$ pidolate was to be discontinued if the subjects experienced significant clinical or biochemical signs of $\mathrm{Mg}$ toxicity.

Hematological and biochemical studies. CBC, erythrocyte indices, and reticulocyte percentage were measured with a Technicon $\mathrm{H}^{*} 3 \mathrm{He}$ matology analyzer (Bayer Corp., Diagnostics Division, Tarrytown, NY) (22-24). After measuring directly the volume (V) and hemoglobin concentration (HC) of individual erythrocytes and reticulocytes, the instrument calculates the hemoglobin content $(\mathrm{CH})$ of individual cells using the formula $V \times H C=C H$. It also generates histograms and calculates distribution widths for each of these measured indices for reticulocytes: cell volume (MCV and RDW, MCVr and RDWr), cell hemoglobin concentration (CHCM and HDW, CHCMr and HDWr), and cell hemoglobin content ( $\mathrm{MCH}$ and $\mathrm{CHDW}, \mathrm{CHr}$ and $\mathrm{CHDWr}$ ). $\mathrm{MCHC}$ is calculated from the measured hemoglobin and hematocrit values. We defined the number of dense SS erythrocytes as the absolute number of erythrocytes with $\mathrm{CHCM}>38 \mathrm{~g} / \mathrm{dl}$, from the direct cytometric measurement of CHCM.

The Bayer $\mathrm{H}^{*} 3$ analyzer identifies reticulocytes based on their absorbance after staining with the dye Oxazine 750. The amount of light absorbed by the reticulocytes is directly proportional to their RNA content (24).

We measured plasma levels of BUN, creatinine, ALT, AST, and other blood chemistries using standard assays on a chemistry analyzer (Boehringer/Hitachi 911; Hitachi Sci. Instr., Mountain View, CA).

Erythrocyte composition, density, and ion transport studies. Erythrocyte cation content and erythrocyte density distribution curves, using phthalate esters, were determined as described previously (25). We evaluated three parameters in the phthalate esters assay (26): (a) $\mathrm{D}_{50}$, or median density, the density value that divides the red cell population in half; $(b) \mathrm{R}_{60}$, or median $60 \%$ density range obtained after subtracting the $20 \%$ lightest and densest fractions, quantifies the spread in cell densities which is characteristic of SS disease; and (c) percentage of dense cells, corresponding to the percentage of cells with density $>1.120$. With these values and the absolute erythrocyte count obtained from the CBC, the absolute number of so-defined dense cells per microliter can be calculated. Repeated measurements in dif- ferent patients indicate that the reproducibility of these assays (expressed as mean $\pm \mathrm{SD}$ of the individual cell volume for eight patients) is $0.11 \pm 0.07 \%$ for $D_{50}$ and $12.7 \pm 7.3 \%$ for the percentage of dense cells.

Plasma and buffy coat were removed after centrifugation at 1,200 $\mathrm{g}$ for $10 \mathrm{~min}$, and the cells were washed four times with choline wash solution containing $152 \mathrm{mmol} /$ liter choline chloride, $1 \mathrm{mmol} /$ liter TrisMops, pH 7.4, at $4^{\circ} \mathrm{C}$. Erythrocyte $\mathrm{K}$ and $\mathrm{Na}$ contents were determined with atomic absorption spectrometry. Repeated measurements in different patients indicate that the reproducibility of the erythrocyte $\mathrm{K}$ content assay (expressed as mean $\pm \mathrm{SD}$ of the individual cell volume for eight patients) is $4.6 \pm 2.7 \%$.

$\mathrm{K}-\mathrm{Cl}$ cotransport from fresh cells was measured as chloride-dependent net $\mathrm{K}$ efflux into hypotonic medium. Flux medium for chloridedependent $\mathrm{K}$ efflux contained (in mmol/liter) $100 \mathrm{Na}, 1 \mathrm{Mg}$ (the anion either $\mathrm{Cl}^{-}$or $\mathrm{NO}_{3}^{-}$), 10 glucose and 10 Tris-Mops $\left(\mathrm{pH} 7.4\right.$ at $\left.37^{\circ} \mathrm{C}\right)$. Chloride-dependent $\mathrm{K}$ efflux was calculated from the difference between $\mathrm{K}$ efflux into chloride and that into nitrate. Efflux rates were calculated from net flux measurements taken after 5 and $25 \mathrm{~min}$ of incubation at $37^{\circ} \mathrm{C}$. Repeated measurements in different patients indicate that the reproducibility of these assays (expressed as mean \pm SD of the individual $\mathrm{CV}$ for eight patients) is $10.9 \pm 5 \%$.

The maximal rates of $\mathrm{Na}-\mathrm{K}$ pump and $\mathrm{Na}-\mathrm{K}-2 \mathrm{Cl}$ cotransport systems were measured in cells containing equal amounts of $\mathrm{Na}$ and $\mathrm{K}$ ( $\sim 50 \mathrm{mmol} /$ liter of cells each). Erythrocytes were treated with the nystatin technique to modify the intracellular cation composition (27). The nystatin-loading solution contained (in mmol/liter) $70 \mathrm{NaCl}$, $70 \mathrm{KCl}$, and 55 sucrose. Na-K pump was estimated as the ouabainsensitive fraction on $\mathrm{Na}$ efflux into a medium containing (in $\mathrm{mmol} / \mathrm{li}$ ter) 130 choline chloride and $10 \mathrm{KCl}$. Triplicate samples were incubated for $5 \mathrm{~min}$ and $25 \mathrm{~min}$ at $37^{\circ} \mathrm{C}$. The ouabain concentration was $0.1 \mathrm{mmol} /$ liter. $\mathrm{Na}-\mathrm{K}-2 \mathrm{Cl}$ cotransport was estimated as the bumetanide-sensitive fraction of $\mathrm{Na}$ efflux into a medium containing (in $\mathrm{mmol} /$ liter) 140 choline chloride and 0.1 ouabain. The efflux times were 5 and $25 \mathrm{~min}$ at $37^{\circ} \mathrm{C}$ with triplicate samples. The bumetanide concentration was $0.01 \mathrm{mmol} / \mathrm{liter}$. All media contained (in mmol/liter) $1 \mathrm{MgCl}_{2}, 10$ glucose, and 10 Tris-Mops ( $\mathrm{pH} 7.4$ at $37^{\circ} \mathrm{C}$ ).

Osmotic gradient ektacytometry. We used osmotic gradient ektacytometry to quantitate cellular deformability, which is regulated by surface area, surface area-to-volume ratio, and state of hydration of red cells (28). We performed osmotic gradient ektacytometry on fresh blood samples in five of the patients enrolled in this trial, at baseline and after $4 \mathrm{wk}$ of $\mathrm{Mg}$ supplementation. Two of these patients were also studied after 2 wk of therapy. We mixed erythrocytes continuously with a $4 \%$ polyvinylpyrrolidone solution of gradually increasing osmolality (from 60 to $450 \operatorname{mos}$ ), and recorded the deformability index with an ektacytometer (Bayer Corp., Diagnostics Division) as a function of osmolality at a constant applied shear stress of 170 dynes $/ \mathrm{cm}^{2}$. The following variables were quantified: $(a) \mathrm{O}_{\min }$, the osmolality at which the deformability index (DI) reaches a minimum in the hypotonic region of the gradient, corresponds to the osmolality at which $50 \%$ of the red cells hemolyze in a standard osmotic fragility test. This index provides a measure of the average surface area-to-volume ratio of the erythrocytes. (b) $\mathrm{DI}_{\max }$, the maximum value of the DI attained at physiologically relevant osmolality, is quantitatively related to the mean surface area of red cells. (c) $\mathrm{O}^{\prime}$, the osmolality value in the hyperosmolar region at which the DI reaches half the maximum value, provides information on the hydration state of the erythrocytes.

Osmotic gradient ektacytometry quantitates the surface area-to-volume ratio, the membrane surface area, and the state of hydration of erythrocytes in the blood sample. Normal ranges for these different parameters had been established in our laboratory with blood samples from 144 healthy adult blood donors (29).

Erythrocytes of patients with SS disease show, to a variable extent, a left shift in $\mathrm{O}_{\min }$, a left shift in $\mathrm{O}^{\prime}$, indicative of red cell dehydration, and a decrease in $\mathrm{DI}_{\max }$, which most likely reflects heterogeneity in cell water content rather than a uniform reduction in surface area. 


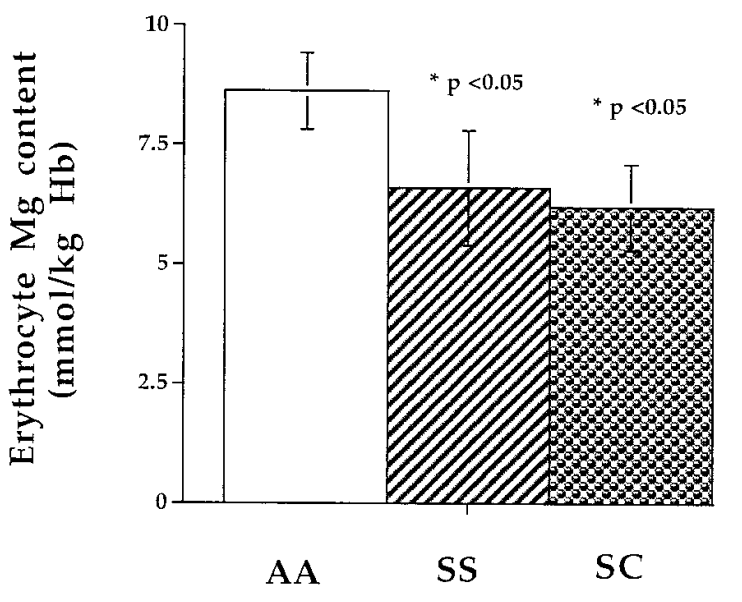

Figure 1. Erythrocyte $\mathrm{Mg}$ content (mean $\pm \mathrm{SD}$ ) in normal controls $(A A, n=17)$ and in untransfused patients with SS $(n=21)$ and SC $(n=24)$ disease.

Statistical analysis. All values are means \pm SD. Comparisons of separate variables between baseline state and values after 14 and $28 \mathrm{~d}$ of treatment were performed using two-tailed Student's $t$ test. Comparison of more than two groups was performed by one-way ANOVA with Tukey's test for post hoc comparison of the means (30).

\section{Results}

Serum and erythrocyte $M g$ in SS and SC disease. Fig. 1 presents data on the erythrocyte $\mathrm{Mg}$ content of patients with SS or SC disease and normal control subjects. The SS and SC erythrocytes have a reduced erythrocyte $\mathrm{Mg}$ content compared with normal controls (in $\mathrm{mmol} / \mathrm{kg}$ hemoglobin, 6.6 $\pm 1.2, n=21$, $6.2 \pm 0.9, n=24$, and 8.62 $\pm 0.8, n=17, P<0.05$, respectively). Measurements of plasma $\mathrm{Mg}$ showed no differences between SS and SC patients and normal controls (data not shown).

The effect of dietary $\mathrm{Mg}$ supplementation on SS erythrocyte $\mathrm{Mg}, \mathrm{Na}$, and $\mathrm{K}$ contents. Table I presents data obtained from measurements of plasma and erythrocyte $\mathrm{Mg}$ in the $10 \mathrm{SS}$ disease patients treated with $\mathrm{Mg}$ pidolate. Dietary Mg supplementation did not affect plasma $\mathrm{Mg}$, which remained unchanged from baseline. A significant increase in erythrocyte $\mathrm{Mg}$ content was observed after 14 and $28 \mathrm{~d}$ of $\mathrm{Mg}$ supplementation, with values similar to those of normal cells at day 14 , but somewhat higher than normal cells at day 28. These changes are much greater than those obtained with slightly

Table I. Plasma and Erythrocyte Mg at Baseline and during Dietary Mg Supplementation

\begin{tabular}{ccc}
\hline Time & Plasma Mg & Erythrocyte Mg \\
\hline$d$ & $m M$ & $m m o l / k g ~ H b$ \\
Baseline & $0.862 \pm 0.057(11)$ & $5.18 \pm 0.24(11)$ \\
14 & $0.954 \pm 0.11(10)$ & $9.34 \pm 2.3(10)^{*}$ \\
28 & $0.937 \pm 0.09(10)$ & $11.4 \pm 1.2(10)^{\ddagger}$ \\
\hline
\end{tabular}

Patients were treated with oral $\mathrm{Mg}$ pidolate at $0.6 \mathrm{meq} / \mathrm{kg}$ body wt $/ \mathrm{d}$. Data are presented as means \pm SD ( $n$ of determinations). $* P<0.05$ and ${ }^{\ddagger} P<0.005$ compared to baseline.

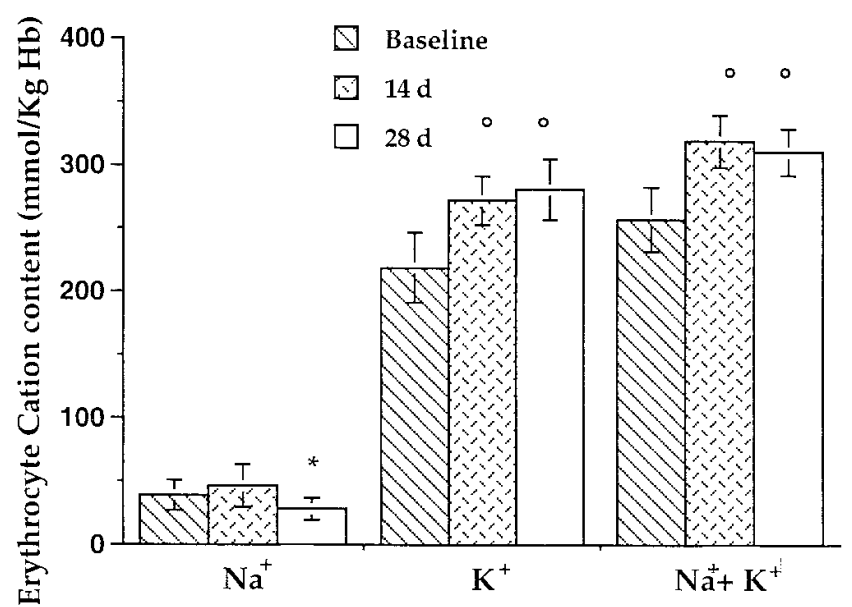

Figure 2. Erythrocyte cation content in patients with SS disease at baseline and after 14 and $28 \mathrm{~d}$ of oral $\mathrm{Mg}$ pidolate supplements $(0.6$ meq $/ \mathrm{kg}$ body wt $/ \mathrm{d}, n=10) . * P<0.05$ and ${ }^{\circ} P<0.005$.

lower doses of $\mathrm{Mg}$ pidolate in subjects with diabetes mellitus, who had normal baseline erythrocyte $\operatorname{Mg}$ content $(18,19)$.

Fig. 2 presents the data obtained from measurements of erythrocyte $\mathrm{Na}$ and $\mathrm{K}$ content. As shown in previous publications $(3,9)$, baseline erythrocyte $\mathrm{K}$ was markedly lower, and erythrocyte $\mathrm{Na}$ was higher compared with normal controls. Statistically significant increases in SS erythrocyte K and total cation content were noted at day 14 and persisted at day 28 . There was also a statistically significant decrease in cell $\mathrm{Na}$ content at day 28 only.

The effect of dietary $\mathrm{Mg}$ supplementation on the major ion transport pathways of SS erythrocytes. Fig. 3 presents data obtained from measurements of erythrocyte $\mathrm{K}-\mathrm{Cl}$ cotransport, $\mathrm{Na}-\mathrm{K}$ pump, and $\mathrm{Na}-\mathrm{K}-\mathrm{Cl}$ cotransport activities. We observed a significant reduction in $\mathrm{K}-\mathrm{Cl}$ cotransport activity at day 14 , with a further decrease at day 28 . This finding is most likely related to the increased cell $\mathrm{Mg}$ content, and provides a mechanistic explanation for the observed increase in cell $\mathrm{K}$ content.

Significant changes were also observed in the maximal rate of the Na-K pump, which was reduced abnormally at baseline in SS erythrocytes, as previously reported by other investigators $(3,31) .28 \mathrm{~d}$ of dietary $\mathrm{Mg}$ supplementation induced a significant increase in the maximal rate of this transporter, which reached values similar to those observed in normal controls. This finding suggests that either the total number of pumps per erythrocyte or the catalytic rate of the pump had been increased as a consequence of the increased erythrocyte $\mathrm{Mg}$ content.

No significant changes were observed in the maximal rate of the Na-K-Cl cotransport, the other major cotransporter of erythrocytes.

The effect of dietary $\mathrm{Mg}$ supplementation on the cellular deformability of SS erythrocytes. Fig. 4 and Table II present data obtained from osmotic gradient ektacytometry determinations. Studies were carried out at baseline and after $28 \mathrm{~d}$ of $\mathrm{Mg}$ supplementation in five patients. Fig. 4 shows that in one representative patient, a significant change in the erythrocyte deformability index occurred with dietary $\mathrm{Mg}$ supplementation, in the direction of the values observed in normal controls. A statistically significant increase in $\mathrm{O}^{\prime}$ values indicated an improved hydration state of the erythrocytes (Table II). These 
A

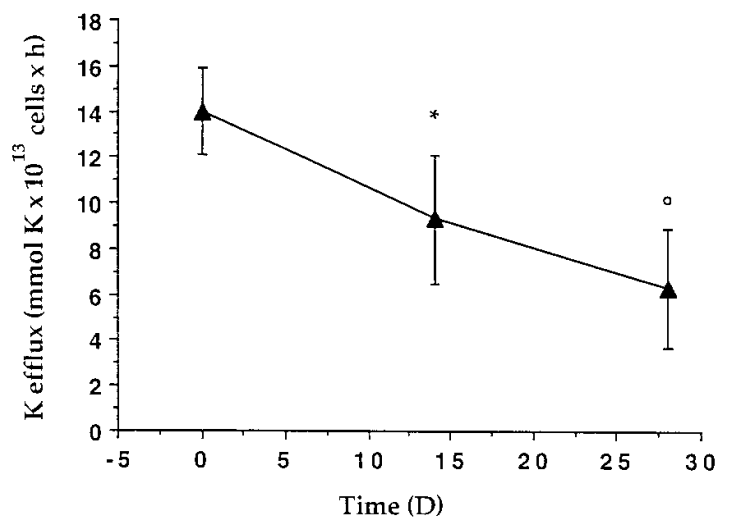

B

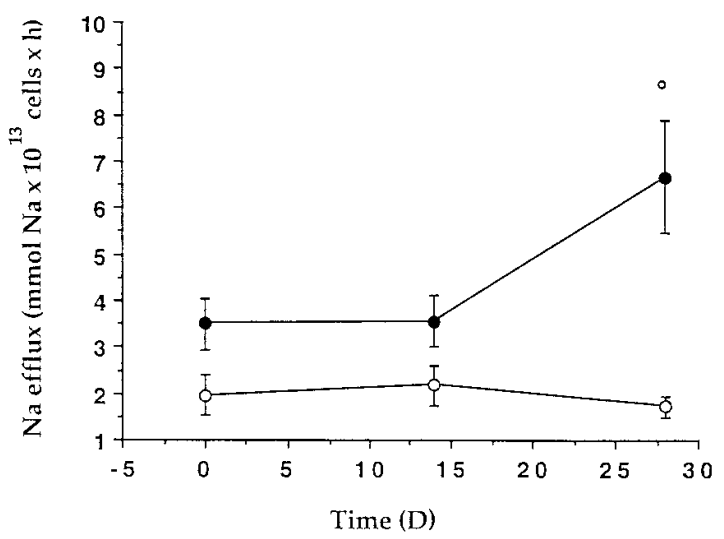

Figure 3. Activity of erythrocyte K-Cl cotransport $(\boldsymbol{\Delta})(A)$ and Na-K pump $(\bullet)$ and Na-K-Cl cotransport $(O)(B)$ at baseline, and after 14 and $28 \mathrm{~d}$ of oral $\mathrm{Mg}$ pidolate supplements $(0.6 \mathrm{meq} / \mathrm{kg}$ body wt $/ \mathrm{d}, n=$ $10)$ in patients with SS disease. ${ }^{*} P<0.05$ and ${ }^{\circ} P<0.005$.

studies do not allow ruling out possible effects of $\mathrm{Mg}$ on cell deformability that are independent of the improved hydration state.

The effects of dietary Mg supplementation on hematological indices for erythrocytes and reticulocytes. Table II presents results obtained from the determination of several hematological and biochemical parameters. A trend for an increase in hemoglobin levels did not reach statistical significance. No significant changes occurred in $\mathrm{MCV}, \mathrm{MCHC}$, and $\mathrm{MCH}$, nor in the distribution widths RDW and HDW and values for $\mathrm{MCH}$ (data not shown).

A significant reduction occurred in the absolute reticulocyte count after $28 \mathrm{~d}$ (Table II). This reduction was associated with a significant reduction in the absolute number of reticulocytes with high staining intensity, which corresponds to the most immature fraction of reticulocytes, and which has the highest residual RNA content. No significant changes occurred in the absolute number of reticulocytes with low and medium staining intensity (data not shown). Other cellular characteristics of the reticulocytes were unchanged, such as reticulocyte

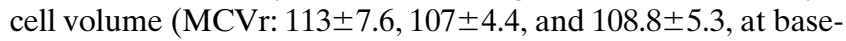
line, 14 , and $28 \mathrm{~d}$, respectively) and reticulocyte cell hemoglobin concentration (CHCMr: $26.3 \pm 2.1,27.4 \pm 1.5$, and $27 \pm 1.0$ at baseline, 14, and $28 \mathrm{~d}$, respectively).

Table II additionally shows significant changes in the density of the SS erythrocytes with Mg therapy. The median density of erythrocytes fell significantly after 14 and $28 \mathrm{~d}$ of dietary $\mathrm{Mg}$ supplementation (Table II). The middle density range $\left(\mathrm{R}_{60}\right)$, which quantifies the heterogeneous distribution of erythrocyte densities, was also reduced significantly with dietary $\mathrm{Mg}$ supplementation.

Fig. 5 shows that a significant reduction in the absolute number of dense, dehydrated SS erythrocytes, was observed after 14 and $28 \mathrm{~d}$ of $\mathrm{Mg}$ supplementation. These data were obtained with the phthalate density profile method, which quantifies cells with density $>1.120$. Estimates of dense cells based on the Bayer $\mathrm{H}^{*} 3$ analyzer, which quantifies erythrocytes with a $\mathrm{CHCM}$ value $>38 \mathrm{~g} / \mathrm{dl}$, also showed a significant reduction of dense cells after $28 \mathrm{~d}$ of $\mathrm{Mg}$ therapy (data not shown).

Clinical and side effects of dietary $\mathrm{Mg}$ supplementation. No significant side effects of dietary $\mathrm{Mg}$ supplementation were noted in this trial, with the exception of transient diarrhea in 1 of the 10 patients. No significant changes were observed in plasma levels of ALT, AST, or indirect bilirubin (not shown).

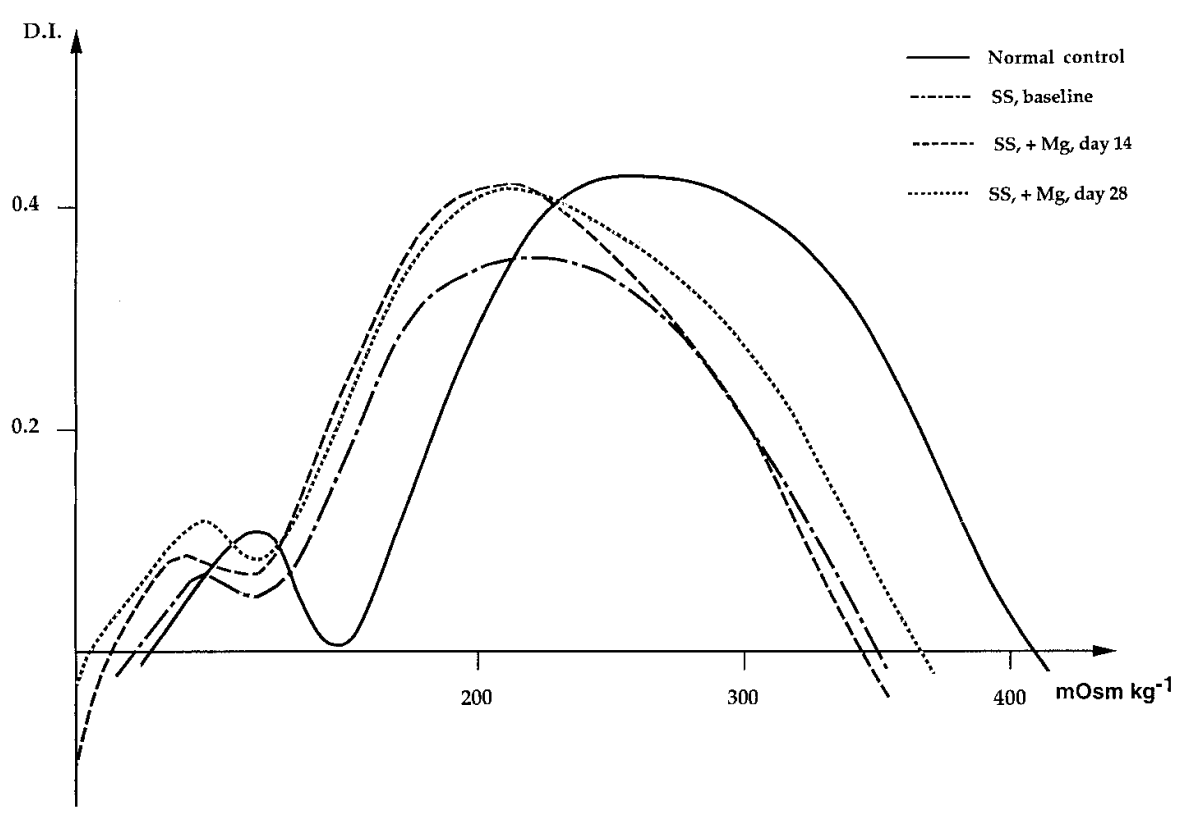

Figure 4. Osmotic deformability profile for erythrocytes collected from a patient with SS disease at baseline and after 14 and $28 \mathrm{~d}$ of oral $\mathrm{Mg}$ pidolate supplementation $(0.6 \mathrm{meq} / \mathrm{kg}$ body wt/d). A profile of normal control cells is also presented. A significant shift in $\mathrm{O}^{\prime}$ indicates an improved hydration state of the SS erythrocytes after Mg supplementation. 
Table II. Hematological Parameters in Sickle Cell Patients at Baseline and during Mg Supplementation

\begin{tabular}{|c|c|c|c|c|c|c|c|c|}
\hline Time & $\mathrm{Hb}$ & $\mathrm{MCV}$ & $\mathrm{MCHC}$ & Retic. & HRetic. & $\mathrm{D}_{50}$ & $\mathrm{R}_{60}$ & $\mathrm{O}^{\prime}$ \\
\hline$d$ & $g / d l$ & $f l$ & $g / d l$ & $10^{3} / \mu l$ & $10^{3} / \mu l$ & & & $\operatorname{mos} M \mathrm{~kg}^{-1}$ \\
\hline Baseline & $8.1 \pm 1.0$ & $90.2 \pm 9.0$ & $33.2 \pm 1.4$ & $285 \pm 72$ & $30.2 \pm 10.2$ & $1.098 \pm 0.002$ & $0.013 \pm 0.003$ & $296.4 \pm 20.1$ \\
\hline 14 & $8.2 \pm 1.0$ & $89.5 \pm 8.9$ & $33.5 \pm 1.5$ & $269 \pm 73.5$ & $30.6 \pm 18.8$ & $1.091 \pm 0.005^{\ddagger}$ & $0.010 \pm 0.004 *$ & ND \\
\hline 28 & $8.5 \pm 1.1$ & $90.9 \pm 9.0$ & $32.4 \pm 0.8$ & $228 \pm 34.3^{*}$ & $23.9 \pm 6.8^{*}$ & $1.092 \pm 0.004^{\ddagger}$ & $0.010 \pm 0.001^{*}$ & $306.4 \pm 15.3^{*}$ \\
\hline
\end{tabular}

Patients were treated with oral $\mathrm{Mg}$ pidolate at $0.6 \mathrm{meq} / \mathrm{kg} / \mathrm{d}$. Data are presented as mean $\pm \mathrm{SD}(n=10) . * P<0.05$ and ${ }^{\ddagger} P<0.005$ compared to baseline. Retic., reticulocytes. Hretic., high staining intensity reticulocytes. ND, not determined.

Plasma Mg, BUN, and creatinine did not change during $\mathrm{Mg}$ supplementation (Table I, and data not shown).

\section{Discussion}

The role of erythrocyte $\mathrm{Mg}$ content in regulating $\mathrm{K}-\mathrm{Cl}$ cotransport had been demonstrated in erythrocytes of normal human controls (15) and of patients with SS disease $(16,17)$. Oral administration of $\mathrm{Mg}$ has been shown to reduce dehydration and increase hemoglobin levels in the SAD mouse, a transgenic murine model of SS disease (20). Studies in diabetic patients have shown that dietary $\mathrm{Mg}$ supplements can increase erythrocyte $\mathrm{Mg}$ content $(18,19)$. Based on this preliminary evidence, we tested the hypothesis that dietary $\mathrm{Mg}$ supplements could increase erythrocyte $\mathrm{Mg}$, inhibit $\mathrm{K}-\mathrm{Cl}$ cotransport, and reduce dehydration in patients with SS disease.

We found erythrocyte $\mathrm{Mg}$ content of SS and SC patients to be reduced compared with normal controls (Fig. 1). A large study also reported lower levels of erythrocyte $\mathrm{Mg}$ in SS disease (32). Most of the $\mathrm{Mg}$ contained in erythrocytes is bound to cellular proteins, ATP, and 2,3-diphosphoglycerate. The normal erythrocyte membrane is functionally impermeable to $\mathrm{Mg}$. The $\mathrm{Na} / \mathrm{Mg}$ exchanger, which extrudes $\mathrm{Mg}$ from the cell in

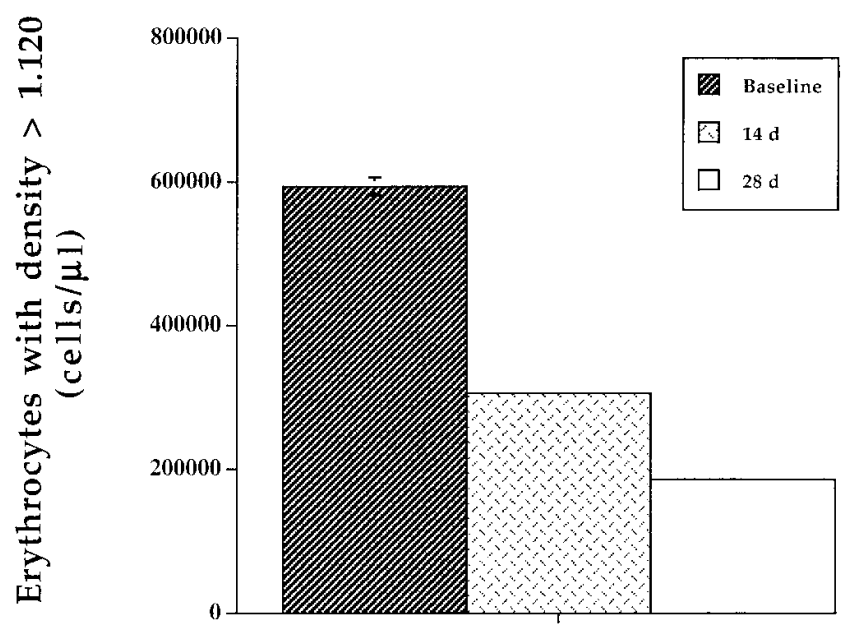

Figure 5. Absolute number of dense erythrocytes (cells/ $\mu$ l) at baseline, and after 14 and $28 \mathrm{~d}$ of oral $\mathrm{Mg}$ supplements in patients with SS disease. Data obtained with phthalate density profiles. Dense cells were defined as the percentage of cells with density $>1.120$. Absolute number of dense erythrocytes was obtained from the percentage of dense cells and the erythrocyte count obtained with the Bayer $\mathrm{H}^{* 3}$ analyzer. exchange for $\mathrm{Na}$, provides the only known mechanism for $\mathrm{Mg}$ loss in normal erythrocytes (33), but remains poorly understood. This system most likely mediates the decrease in erythrocyte $\mathrm{Mg}$ observed with cell age (or density): a two to fourfold difference in cell $\mathrm{Mg}$ has been described between high and low density fractions of human erythrocytes $(34,35)$. A preliminary report of increased activity of the $\mathrm{Na} / \mathrm{Mg}$ exchanger in Mg-loaded SS erythrocytes (36) might provide an explanation for the reduced $\mathrm{Mg}$ content of SS cells. The reduction in total cell $\mathrm{Mg}$ content is evident particularly in dense SS erythrocytes. In addition, these cells exhibit an abnormal increase in free $\mathrm{Mg}$ due to reduction in the intracellular $\mathrm{Mg}$ buffering capacity (31). This may promote further $\mathrm{Mg}$ loss upon sickling, because the free $\mathrm{Mg}$ gradient is outwardly directed, and sickling has been shown to increase the permeability of the erythrocyte membrane to $\mathrm{Mg}$ (31). These data indicate that the reduced erythrocyte $\mathrm{Mg}$ of SS erythrocytes can be restored to normal or above normal values in patients treated with dietary $\mathrm{Mg}$ supplements (Table I). The intracellular distribution of $\mathrm{Mg}$ was not studied in these patients. Thus, we cannot estimate the relative magnitude of the changes in free erythrocyte $\mathrm{Mg}$.

The normalization of erythrocyte $\mathrm{Mg}$ content is associated with a significant reduction in $\mathrm{K}-\mathrm{Cl}$ cotransport activity and with increased $\mathrm{K}$ content. The reduced $\mathrm{K}-\mathrm{Cl}$ cotransport can be interpreted as a direct effect of increased $\mathrm{Mg}$ content, although indirect effects are possible, including reduction in absolute reticulocyte number or diminished oxidative damage. $\mathrm{K}-\mathrm{Cl}$ cotransport is the primary mechanism for dehydration of transferrin receptor-positive reticulocytes (37).

$\mathrm{Mg}$ is an important regulator of ion transport across cellular membranes. $\mathrm{Mg}$ is an essential cofactor for $\mathrm{Na}$-stimulated phosphorylation of the Na-K ATPase (38). A [Mg]/[ATP $]$ ratio near one is optimal for $\mathrm{Na}-\mathrm{K}$ pump activity, with inhibition at higher and lower ratios. It has been demonstrated that the reduced Na-K pump activity of dense SS erythrocytes can be normalized when a proper $[\mathrm{Mg}] /[\mathrm{ATP}]$ ratio is restored (31). We interpret the observed changes in the maximal rate of the Na-K pump (Fig. 3) as an indication that the optimal [Mg]/ [ATP] ratio has been restored with dietary $\mathrm{Mg}$ supplements, although cell ATP content was not measured in this study.

A finding shared by this clinical trial and our recently published report on the use of clotrimazole in SS disease (14) is the observation of a reduction in the number of circulating dense SS erythrocytes. These two studies together indicate that both the Gardos channel and the $\mathrm{K}-\mathrm{Cl}$ cotransporter are involved in the in vivo generation of dense SS cells, as recent in vitro studies suggested (39).

Several uncontrolled studies have reported beneficial ef- 
fects of oral administration of $\mathrm{Mg}$ citrate or intravenous administration of $\mathrm{Mg}$ sulfate in patients with SS disease $(40,41)$. However, a 7-d course of oral Mg supplementation using $\mathrm{Mg}$ citrate did not change erythrocyte survival in three patients with SS disease (42).

Although no changes in $\mathrm{Hb}$ levels were demonstrated in this study, the reduction in both absolute reticulocyte counts and percentage of immature reticulocytes induced by $\mathrm{Mg}$ therapy suggests a possible improvement of the anemia. However, an effect of the increased $\mathrm{Mg}$ content on reticulocyte maturation cannot be ruled out. The improved erythrocyte deformability observed in this study could also result in improved survival or oxygen delivery.

This study provides the first in vivo evidence for a role of $\mathrm{K}-\mathrm{Cl}$ cotransport in SS erythrocyte dehydration. The data justify proposing oral $\mathrm{Mg}$ pidolate as a potential therapeutic strategy for preventing erythrocyte dehydration in SS disease.

\section{Acknowledgments}

We thank Marty Sorette of Bayer Corp. for data analysis.

This work was supported by National Institutes of Health grants from the National Heart, Lung, and Blood Institute (P60-HL15157), the National Institute of Diabetes and Digestive and Kidney Diseases (R01-DK50422), from General Clinical Research Center grant M01 RR02172, and by Teleton grant E.491.

\section{References}

1. Eaton, W.A., and J. Hofrichter. 1987. Hemoglobin S gelation and sickle cell disease. Blood. 70:1245-1266.

2. Noguchi, C.T., G.P. Rodgers, and A.N. Schechter. 1989. Intracellular polymerization. Disease severity and therapeutic predictions. Ann. NY Acad. Sci. 565:75-82.

3. Clark, M.R., C.E. Morrison, and S.B. Shohet. 1978. Monovalent cation transport in irreversibly sickle cells. J. Clin. Invest. 62:329-337.

4. Bertles, J.F., and P.F.A. Milner. 1968. Irreversibly sickled erythrocytes: a consequence of the heterogeneous distribution of hemoglobin types in sickle cell anemia. J. Clin. Invest. 47:1731-1741.

5. Platt, O.S., S.H. Orkin, G. Dover, G.P. Beardsley, B. Miller, and D.G. Nathan. 1984. Hydroxyurea enhances fetal hemoglobin production in sickle cell anemia. J. Clin. Invest. 74:652-656.

6. Charache, S., M.L. Terrin, R.D. Moore, G.J. Dover, F.B. Barton, S.V. Eckert, R.P. McMahon, and D.R. Bonds. 1995. Effect of hydroxyurea on the frequency of painful crises in sickle cell anemia. N. Engl. J. Med. 332:1317-1322.

7. Bridges, K.R., G.D. Barabino, C. Brugnara, M. Cho, G.W. Christoph, G. Dover, B. Ewenstein, D.E. Golan, C.R.G. Guttmann, J. Hofrichter et al. 1996. A multiparameter analysis of sickle erythrocytes in patients undergoing hydroxyurea therapy. Blood. 88:4701-4710.

8. Gardos, G. 1958. The function of calcium in the potassium permeability of human erythrocytes. Biochim. Biophys. Acta. 30:653-654.

9. Brugnara, C., H.F. Bunn, and D.C. Tosteson. 1986. Regulation of erythrocyte cation and water content in sickle cell anemia. Science (Wash. DC). 232: 388-390.

10. Joiner, C.H. 1993. Cation transport and volume regulation in sickle red blood cells. Am. J. Physiol. (Cell Physiol. 33) 264:C251-C270.

11. Alvarez, J., M. Montero, and J. Garcia-Sancho. 1992. High affinity inhibition of $\mathrm{Ca}^{2+}$-dependent $\mathrm{K}^{+}$channels by cytochrome P-450 inhibitors. J. Biol. Chem. 267:11789-11793.

12. Brugnara, C., L. De Franceschi, and S.L. Alper. 1993. Inhibition of $\mathrm{Ca}^{2+}$-dependent $\mathrm{K}^{+}$transport and cell dehydration in sickle erythrocytes by clotrimazole and other imidazole derivatives. J. Clin. Invest. 92:520-526.

13. De Franceschi, L., N. Sadane, M. Trudel, S.L. Alper, C. Brugnara, and Y. Beuzard. 1994. Treatment with oral clotrimazole blocks $\mathrm{Ca}^{2+}$-activated $\mathrm{K}^{+}$ transport and reverses erythrocyte dehydration in transgenic SAD mice: a model for therapy of sickle cell disease. J. Clin. Invest. 93:1670-1676.

14. Brugnara, C., B. Gee, C. Armsby, S. Kurth, M. Sakamoto, N. Rifai, S.L. Alper, and O.S. Platt. 1996. Therapy with oral clotrimazole induces inhibition of the Gardos channel and reduction of erythrocyte dehydration in patients with sickle cell disease. J. Clin. Invest. 97:1227-1234.

15. Brugnara, C., and D.C. Tosteson. 1987. Cell volume, $\mathrm{K}$ transport and cell density in human erythrocytes. Am. J. Physiol. (Cell Physiol. 21)252:C269C276.
16. Brugnara, C., and D.C. Tosteson. 1987. Inhibition of K transport by divalent cations in sickle erythrocytes. Blood. 70:1810-1815.

17. Canessa, M., M.E. Fabry, and R.L. Nagel. 1987. Deoxygenation inhibits the volume-stimulated, Cl-dependent $\mathrm{K}^{+}$efflux in SS and young AA cells: a cytosolic $\mathrm{Mg}^{++}$modulation. Blood. 70:1861-1866.

18. Paolisso, G., A. Scheen, D. Cozzolino, G. Di Maro, M. Varricchio, F. D'Onofrio, and P.J. Lefebvre. 1994. Changes in glucose turnover parameters and improvement of glucose oxidation after 4-week magnesium administration in elderly noninsulin-dependent (type II) diabetic patients. J. Clin. Endocrinol. Metab. 78:1510-1514.

19. Borella, P., G. Ambrosini, M. Concari, and A. Bargellini. 1993. Is magnesium content in erythrocytes suitable for evaluating cation retention after oral physiological supplementation in marginally magnesium-deficient subjects? Magnes. Res. 6:149-153.

20. De Franceschi, L., Y. Beuzard, H. Jouault, and C. Brugnara. 1996. Modulation of erythrocyte potassium-chloride cotransport, potassium content and density by dietary magnesium intake in transgenic SAD mouse. Blood. 88:27382744 .

21. Britton, J., I. Pavord, K. Richards, A. Wisniewski, A. Knox, S. Lewis, A Tattersfield, and S. Weiss. 1994. Dietary magnesium, lung function, wheezing, and airway hyperreactivity in random adult population sample. Lancet. 344: $357-362$.

22. Mohandas, N., Y.R. Kim, D.H. Tycko, J. Orlik, J. Wyatt, and W. Groner. 1986. Accurate and independent measurement of volume and hemoglobin concentration of individual red cells by laser light scattering. Blood. 68: 506-513.

23. Mohandas, N., A. Johnson, J. Wyatt, L. Croisille, J. Reeves, D. Tycko, and W. Groner. 1989. Automated quantitation of cell density distribution and hyperdense cell fraction in RBC disorders. Blood. 74:442-447.

24. Brugnara, C., M.J. Hipp, P.J. Irving, H. Lathrop, P.A. Lee, E.M. Minchello, and J. Winkelman. 1994. Automated reticulocyte counting and measurement of reticulocyte cellular indices: evaluation of the Miles $\mathrm{H}^{*} 3$ blood analyzer. Am. J. Clin. Pathol. 102:623-632.

25. Danon, D., and Y. Marikovsky. 1964. Determination of density distribution of red cell population. J. Lab. Clin. Med. 64:668-674.

26. Rodgers, G.P., A.N. Schechter, and C.T. Noguchi. 1985. Cell heterogeneity in sickle cell disease: quantitation of the erythrocyte density profile. $J$. Lab. Clin. Med. 106:30-37.

27. Brugnara, C., A. Kopin, H.F. Bunn, and D.C. Tosteson. 1985. Regulation of cation content and cell volume in erythrocytes from patients with homozygous hemoglobin C disease. J. Clin. Invest. 75:1608-1617.

28. Clark, M.R., M. Narla, and S.B. Shohet. 1983. Osmotic gradient ektacytometry: comprehensive characterization of red cell volume and surface maintenance. Blood. 61:899-910.

29. Cynober, T., M. Narla, and G. Tchernia. 1996. Red cell abnormalities in hereditary spherocytosis: relevance to diagnosis and understanding of the variable expression of clinical severity. J. Lab. Clin. Med. 128:259-269.

30. Godfrey, K. 1985. Comparing the means of several groups. $N$ Engl. J. Med. 313:1450-1456.

31. Ortiz, O.E, V.L. Lew, and R.M. Bookchin. 1990. Deoxygenation permeabilizes sickle cell anaemia red cells to magnesium and reverses its gradient in the dense cells. J. Physiol. (Lond.). 427:211-226.

32. Olukoga, A.O., H.O. Adewoye, R.T. Erasmus, and M.A. Adedoyin. 1990. Erythrocyte and plasma magnesium in sickle-cell anaemia. East Afr. Med. J. 67:348-354.

33. Feray, J.C., and R. Garay 1986. An $\mathrm{Na}^{+}$-stimulated $\mathrm{Mg}^{2+}$ transport system in human red blood cells. Biochim. Biophys. Acta. 856:76-84.

34. Bernstein, R.E. 1959. Alterations in metabolic energetics and cation transport during aging of red cells. J. Clin. Invest. 38:1572-1586.

35. Ginsburg, S., J.G. Smith, F.M. Ginsburg, J.Z. Reardon, and J.K. Aikawa. 1962. Magnesium metabolism of human and rabbit erythrocytes. Blood. 20:722-729.

36. Feray, J.C., Y. Beuzard, and R.P. Garay. 1988. Na/Mg exchange in sickle cells. VI International Magnesium Symposium. 22a. (Abstr.).

37. Franco, R.S., M. Palascak, H. Thompson, and C.H. Joiner. 1995. K/C cotransport activity in light versus dense transferrin receptor-positive reticulocytes. J. Clin. Invest. 95:2573-2580.

38. Flatman, P.W., and V.L. Lew. 1981. The magnesium-dependence of sodium-pump-mediated sodium-potassium and sodium-sodium exchange in intact human red cells. J. Physiol. (Lond.). 315:421-446.

39. Franco, R.S., M. Palascak, H. Thompson, D.K. Rucknagel, and C.H Joiner. 1996. Dehydration of transferrin receptor-positive sickle reticulocytes during continuous or cyclic deoxygenation: role of $\mathrm{KCl}$ cotransport and extracellular Ca. Blood. 88:4359-4365.

40. Anstall, H.B., R.G. Huntsman, H. Lehmann, G.H. Hayward, and D. Weitzman. 1959. The effect of magnesium on blood coagulation in human subjects. Lancet. 1:814-815.

41. Lehmann, H. 1963. Treatment of sickle cell anemia. Br. Med. J. 1:11581159.

42. Basu, A.K., and A.W. Woodruff. 1966. Effect of acetazolamide and magnesium therapy on erythrocyte survival in sickle-cell anemia and sickle-cellhaemoglobin-C disease. Trans. R. Soc. Trop. Med. Hyg. 60:64-69. 